\title{
IAMJ
}

INTERNATIONAL

AYURVEDIC

MEDICAL JOURNAL

do) $\bigcirc$ (

\section{A COMPARATIVE CLINICAL EVALUATION OF KATPHALADI CHURNA AND PIPPALYADI CHURNA IN MANAGEMENT OF TAMAKA SWASA}

\author{
Ashutosh Kr. Bhardwaj', Prashanth Bhat ${ }^{2}$
}

(B.A.M.S., M.D. (Ayu) Assistant Professor, Government Ayurved College \& Hospital, Kadamkuan, Patna, Bihar $-800003)$, India

Guide, M.D (Ayu) Professor \& HOD Dept. of Kayachikits, A.L.N. Rao Memorial Ayurvedic College \& Hospital, Chikmanglur, Koppa, Karnataka, India

Corresponding Author: dr.ashu943366@gmail.com

https://doi.org/10.46607/iamj02p6012021

(Published online: November 2021)

Open Access

(C) International Ayurvedic Medical Journal, India 2021

Article Received: 03/09/2021 - Peer Reviewed: 05/10/2021 - Accepted for Publication: 25/10/2021

\section{ABSTRACT}

Since time immemorial man has been in a constant endeavor to find the solutions for the life-threatening and agonizing disorders, which afflicts the human race. One such condition is 'Tamaka swasa' which is known by the name Bronchial Asthma in modern parlance, wherein remissions and exacerbations are the typical features, leaving the patient in a pathetic situation. The Objective of the study is to evaluate the comparative efficacy of Katphaladi Churna ${ }^{7}$ and Pippalyadi Churna ${ }^{8}$ in the management of Tamaka Swasa through subjective and objective parameters. The present study registers 40 out of 64 patients. Out of these 24 patients were discontinued. The remaining 40 patients of Tamaka Swasa fulfilling the criteria of diagnosis and inclusive criteria were included in the study, fewer than two groups as distributed patients in Group-A are 20 patients and Group-B is 20 patients. While comparing between the group result shows that Pippalyadi Churna is statistically more effective in Swasa Krichrata (Dyspnoea), Pratishaya (Rhinorrhea), Kanthodavamsa (Hoarseness of voice) and AEC than the Katphaladi Churna. In the overall result, Pippalyadi Churna is more effective than the Katphaladi Churna in the management of Tamaka Swasa. Both of the trial drugs proved to be a safe and effective oral formulation, which helps in the management of Tamaka swasa, when the disease is not too advanced and not associated with complications also when correctly used by the patient as per instructions.

Keywords: Tamaka Swasa, Swasa Krichrata, Pratishaya, Kanthodavamsa, AEC, Katphaladi Churna and Pippalyadi Churna. 


\section{INTRODUCTION}

Tamaka Swasa ${ }^{l}$ is one among the five varieties of Swasa explained in almost all the classics of Ayurve$d a$, which is analogous with Bronchial Asthma mentioned in contemporary medicine. For centuries Tamaka Swasa was reminded to be a challenging and unremitting disease, in both sexes and it may occur at any age.

As a result of urbanization, industrialization, poor sanitation and excessive air pollution, allergic conditions have become rampant in and around society. Large community studies have revealed that $15 \%$ of the population have at least one kind of allergic manifestation, such as asthma, urticaria, food and other allergies $^{2}$. The study also reveals that about $15 \%$ of the children report an episode of wheezing, characteristics of asthma and $5 \%$ of them have a diagnosis of bronchial asthma ${ }^{3}$.

According to different authors, it accounts that 155 million of the world population suffers from Bronchial Asthma which occurs at all ages. About half of cases develop before age 10 and another third occurs before age 40 . In childhood, there is $2: 1$ male / female preponderance but the sex ratio equalizes by age 30. As the ratio of Bronchial Asthma increases, it needs the proper treatment, which can control the disease $^{4}$.

Now we face a resurgence of this illness as a result of massive migration to changes in lifestyles, occupation, food habits, cosmetics, extensive use of fertilizers, pesticides, exposure to the polluted air. In short, the change in the way of lifestyle in all fields has influenced the origin of the disease asthma ${ }^{5}$.

Asatmeindriyarthasamyoga (inappropriate use of Sensory organs), Prajnaparadha (an offence against wisdom) and Parinama (Result) play an important role in the manifestation of all the diseases. This is true in the case of Tamaka Swasa Roga also. Mainly Ghranendriya (Sens Organ), Rasanendriya (Test Organ) and Sparshnendriya (Touch Organ) and their Samyoga (Combination) with respective Asatmya Arthas (Against the Nature) take part in causing Tamaka Swasa. Sharirika (Physical) and Mansika
(Mental) Prajnaparadha, climatic and seasonal variation (Parinama) contribute individually or collectively for worsening the condition of a patient with Tamaka Swasa.

The bronchodilators, corticosteroids or immunotherapy drugs used to treat Bronchial Asthma are proved either ineffective in eradicating the underlying pathology, or their action is limited up to providing symptomatic relief. Thus, long term use of these medicines may cause side effects and intern affects other systems of the body. Irregularities on the part of patients also lead the disease into chronic stage ${ }^{6}$.

The objective of this study on Tamaka Swasa is to suppress the aggravated Dosa without disturbing the non-aggravated Dosa. To enable the patient to achieve normal levels of routine work or normal lung's function and prevent the recurrent episode of Tamaka Swasa.

Here an attempt is made to explain the relevant details, as taken out from the Ayurvedic classics in a comparative manner, supported by modern investigations. All that we need is to strictly adhere to the recipes step by step and practice it to achieve success. In Sarangadhar Samhita Madhyam Khanda $6^{\text {th }}$ Chapter recommended the use of Kataphaladi Churna ${ }^{7}$ in management of Tamaka Swasa and Kashyap Samhita $2^{\text {nd }}$ chapter describes the formulation of Pippalyadi Churna ${ }^{8}$ in management of Swasa Roga. The present study is planned to evaluate the clinical efficacy and comparative effect of the drugs Katphaladi Churna \& Pippalyadi Churna in patients of Tamaka Swasa.

\section{Aim and Objective:}

1. To study in detail the disease Tamak swasa covering both classical and modern literature.

2. To evaluate the clinical efficacy of Kataphaladi Churna \& Pippalyadi Churna in the management of Tamaka Swasa.

3. To compare the clinical efficacy and effect of Kataphaladi Churna with Pippalyadi Churna in Tamaka Swasa.

4. To establish the effective treatment with trail drugs for Tamaka Swasa. 


\section{MATERIALS \& METHODOLOGY:}

A Comparative Clinical Study on the Management of Tamaka Swasa reference to Katphaladi Churna and Pippalyadi Churna was carried out with the following materials and methods.

\section{Materials:}

The drugs selected for the clinical study were:

(a) Katphaladi Churna ${ }^{12}$ :

$\begin{array}{lrl}\text { Katphala } & - & \mathbf{1} \text { part } \\ \text { Puskaramula } & - & \mathbf{1} \text { part } \\ \text { Pippali } & - & \mathbf{1} \text { part } \\ \text { Karkatasringi } & - & \mathbf{1} \text { part } \\ \text { (b) Pippalyadi Churna }{ }^{13} \text { : } & \\ \text { Pippli } & - & \mathbf{1} \text { part } \\ \text { Barangi } & - & \mathbf{1} \text { part } \\ \text { Hingu } & - & \mathbf{1} \text { part } \\ \text { Karkatasringi } & - & \mathbf{1} \text { part } \\ \text { Girika } & - & \mathbf{1} \text { part }\end{array}$

\section{Method of Preparation:}

Above said drugs were taken in dried form, each was put in Khalva Yantra (Stone Mortar Pastel) and pounded to make a fine powder. They all were mixed thoroughly to make a homogenous mixture. Then sieved, stored in airtight containers.

\section{SOURCE OF DATA:}

a. Literary Data: All the available works of literature of Tamaka Swasa reviewed including Ayurvedic classical, contemporary sciences including published scientific papers in reputed journals both in print and online media.

b. Pharmaceutical Source: The formulation Katphaladi Churna and Pippalyadi Churna used as the therapeutical interventions in the study. The raw drugs identified pharmacognostically and Churna prepared in the pharmacy attached to A.L.N. Rao Memorial Ayurvedic Medical College, Koppa as per the standard method of preparation of Churna Kalpana according to $\mathrm{AFI}^{14}$ guidelines.

c. Clinical Data-: Patients diagnosed with Tamaka Swasa were selected incidentally from OPD and IPD of A.L.N. Rao Memorial Ayurveda Medical College and Hospital, Koppa and its associated Hospitals.

\section{Methods of Collection of Data:}

Patients diagnosed with Tamaka Swasa fulfilling the eligibility criteria were incidentally selected \& randomly categorized into 2 groups based on a simple randomization technique.

Study Design: Single-blind randomized clinical trial.

(a) Inclusion Criteria:

- All cases with classical clinical signs and symptoms of Tamaka Swasa included.

- Patients between the age group of 16 to 60 years.

- Disease chronicity less than one year.

(b) Exclusion Criteria:

- Patients of Tamaka Swasa are less than 16 years and more than 60 years of age.

- Pregnant women and lactating mothers.

- Patients suffering from a systemic disorder like Hypertension, Diabetes etc.

- Patients of Tamaka Swasa are associated with COPD, Pulmonary Tuberculosis, Pleural effusion, Emphysema and complicated from chronic lung disease.

Diagnosis: The diagnosis was entirely based on the signs and symptoms of Tamaka swasa mentioned in Ayurvedic classics and modern books.

\section{Method of examination of the patients:}

In this study, the data was collected from the patients with the help of interviews. The detailed data related to general history, history of past illness, present illness family history, food habits, history of treatment taken so far etc, was recorded in the Performa of the case sheet. The systemic examinations of patients were done in detail with due concentration to the respiratory system, and findings were recorded as per the Performa. PEFR was also done to confirm the diagnosis.

\section{Laboratory Investigation:}

- Haematology (Hb\%, TC, DC, ESR)

- Absolute Eosinophil Count.

- Radiology: Chest X-ray. (Whenever necessary)

- Peak Expiratory Flow Meter Reading (PEFR).

Peak expiratory flow meter: A popular instrument for assessing airflow obstruction is the peak flow meter. There is a simpler version called the mini peak flow meter. This machine measures the maximal rate 
of flow which is achieved during forced expiration and most healthy people will achieve values of greater than 400 litres/ minute. Patients with airflow obstruction will have reduced flow rates, with values below 200 litres/ minute being very severe and those below 100 litres extremely severe.
Method: - Measurement of PEFR was made with a peak flow meter. The subject takes a maximal inspiration and then gives a maximum expiratory blast through the instrument. The pointer sticks the point of maximum exertions and the PEFR can be read directly from the scale. On each occasion, three readings are taken, and the best value was recorded.

Table 1: Showing Treatment Schedule

\begin{tabular}{|l|l|l|}
\hline & Group A & Group B \\
\hline Sample Size & 20 Patients & 20 Patients \\
\hline Medicine & Katphaladi Churna & Pippalyadi Churna \\
\hline Dose & $6 \mathrm{gm}$ Thrice in a day & $6 \mathrm{gm}$ Thrice in a day \\
\hline Anupana & Honey & Honey \\
\hline Duration & 4 weeks & 4 weeks \\
\hline Follow Up & 4 weeks & 4 weeks \\
\hline
\end{tabular}

Note-: During treatment patient was advised to follow Pathy-Apathya strictly.

Assessment of Results: The symptoms will be recorded before treatment, during the treatment on the $15^{\text {th }}$ day, $30^{\text {th }}$ day and $45^{\text {th }}$ day. The evaluation had done on the basis of statistical analysis of the results obtained by using the Statistical test "appropriate paired students ' $t$ ' test". During the Follow up time, the response was taken after 30days.

Assessment Criteria: The state of the disease Tamaka swasa, changes after the intervention, improvement or otherwise as determined by adopting standard methods of scoring by means of objective and subjective parameters. The subjective parameters include Swasa Krichata, Ghurghuraka, Kasa, Kaphanishteevana, Pratishaya, Kantodhvamsa, Krichabhashana, Aseeno Labhate Sukham, Aruchi and Nature of attack were analyzed and graded from $0-3$. In the objective Parameter Peak flow meter test was analyzed and graded from $0-3$.

The assessment was done initially before the intervention and thereafter the interval of $8^{\text {th }}$ day, $15^{\text {th }}$ day and $22^{\text {nd }}$ day, $30^{\text {th }}$ day and also the follow up of 30 days after the treatment. These assessment criteria are detailed as follows.

STATISTICAL ANALYSIS: Here the effect of drug administration has been critically analyzed by the statistical data. Descriptive Statistical Data which includes Mean, Standard Deviation (S.D), Standard Error (S.E), t- value and P- value were calculated for all the variables. The post-therapeutic effect of the administered drug is assessed by paired student ' $\mathrm{t}$ ' test. For all the tests, a ' $\mathrm{P}$ ' value of $<0.05$ is considered as the statistical significance level for obtaining an accurate result.

\section{OVERALL ASSESSMENT CRITERIA}

To assess the overall effect of the therapies net results obtained on various parameters of assessment both before and after treatment were taken into consideration. Then it was graded in terms of percentage of relief in symptoms.

RESULTS: The results were obtained in the patients of Tamaka Swasa. As per the assessment criteria, each of the patient's disease features was scored and scoring was done with respect to his/her presenting complaints following a specially prepared Performa before starting the treatment regime (BT) and after completion of treatment (30 days). Respective scores were subjected for statistical analysis using students paired ' $t$ ' and unpaired ' $t$ ' test for within-group and between groups respectively. Following is the obtained result data of the 20 patients in each group of Tamaka Swasa. 
Table 2: Showing Comparative statistical assessment of Group-A and Group-B subjective parameters

\begin{tabular}{|c|c|c|c|c|c|c|c|c|c|}
\hline Subjective Parameters & Group & Mean & $\begin{array}{l}\text { Mean } \\
\text { Difference }\end{array}$ & $\%$ & SD & SE & 't' Value & 'P' Value & Remark \\
\hline \multirow[t]{2}{*}{ Swasa Krichrata } & A & 1.550 & \multirow[b]{2}{*}{-0.450} & \multirow[b]{2}{*}{$29.03 \%$} & 0.605 & 0.135 & \multirow[b]{2}{*}{-2.932} & \multirow[b]{2}{*}{0.006} & \multirow[b]{2}{*}{$\mathrm{SD}^{*}$} \\
\hline & B & 2.000 & & & 0.324 & 0.0725 & & & \\
\hline \multirow[t]{2}{*}{ Ghurghuraka } & A & 1.650 & \multirow[b]{2}{*}{0.150} & \multirow[b]{2}{*}{$9.09 \%$} & 0.587 & 0.131 & \multirow[b]{2}{*}{0.630} & \multirow[b]{2}{*}{0.533} & \multirow[b]{2}{*}{ ND } \\
\hline & $\mathrm{B}$ & 1.500 & & & 0.889 & 0.199 & & & \\
\hline \multirow[t]{2}{*}{ Kasa } & $\mathrm{A}$ & 1.800 & \multirow[b]{2}{*}{0.000} & \multirow[b]{2}{*}{0} & 0.410 & 0.0918 & \multirow[b]{2}{*}{0.000} & \multirow[b]{2}{*}{1.000} & \multirow[b]{2}{*}{ ND } \\
\hline & B & 1.800 & & & 0.410 & 0.0918 & & & \\
\hline \multirow[t]{2}{*}{ Kaphanisteevana } & A & 1.600 & \multirow[b]{2}{*}{-0.350} & \multirow[b]{2}{*}{$21.87 \%$} & 0.598 & 0.134 & \multirow[b]{2}{*}{-1.990} & \multirow[b]{2}{*}{0.054} & \multirow[b]{2}{*}{ ND } \\
\hline & B & 1.950 & & & 0.510 & 0.114 & & & \\
\hline \multirow[t]{2}{*}{ Anidra } & A & 1.250 & \multirow[b]{2}{*}{-0.0500} & \multirow[b]{2}{*}{$4 \%$} & 0.716 & 0.160 & \multirow[b]{2}{*}{-0.191} & \multirow[b]{2}{*}{0.849} & \multirow[b]{2}{*}{ ND } \\
\hline & B & 1.300 & & & 0.923 & 0.206 & & & \\
\hline \multirow[t]{2}{*}{ Prtishaya } & A & 0.650 & \multirow[b]{2}{*}{-0.650} & \multirow[b]{2}{*}{$50 \%$} & 0.745 & 0.167 & \multirow[b]{2}{*}{-2.450} & & \\
\hline & $\mathrm{B}$ & 1.300 & & & 0.923 & 0.206 & & 0.019 & $\mathrm{SD}^{*}$ \\
\hline Kanthodhvamsam & A & 1.300 & & & 0.733 & 0.164 & & & \\
\hline & $\mathrm{B}$ & 1.750 & -0.450 & $34.61 \%$ & 0.550 & 0.123 & -2.196 & 0.034 & $\mathrm{SD}^{*}$ \\
\hline Krichra Bhasana & A & 1.150 & & & 0.875 & 0.196 & & & \\
\hline & B & 1.300 & -0.150 & $13.04 \%$ & 0.923 & 0.206 & -0.527 & 0.601 & ND \\
\hline Asseno labhate Sukham & A & 1.300 & & & 0.657 & 0.147 & & & \\
\hline & $\mathrm{B}$ & 1.250 & 0.0500 & $3.84 \%$ & 0.967 & 0.216 & 0.191 & 0.849 & ND \\
\hline Aruchi & A & 1.500 & & & 0.607 & 0.136 & & & \\
\hline & B & 1.800 & -0.300 & $20 \%$ & 1.005 & 0.225 & -1.143 & 0.260 & ND \\
\hline
\end{tabular}

Table 3: Showing Comparative statistical assessment of Group-A and Group-B subjective parameters

\begin{tabular}{|c|c|c|c|c|c|c|c|c|c|}
\hline Objective Parameters & & Mean & $\begin{array}{l}\text { Mean } \\
\text { Diff. }\end{array}$ & $\%$ & SD & SE & ' $t$ ' Value & 'P' Value & Remark \\
\hline \multirow[t]{2}{*}{ PEFR } & A & 1.050 & \multirow[t]{2}{*}{0.150} & \multirow[t]{2}{*}{$14.28 \%$} & 0.394 & 0.0881 & \multirow[t]{2}{*}{1.125} & \multirow[t]{2}{*}{0.267} & \multirow[t]{2}{*}{ ND } \\
\hline & $\mathrm{B}$ & 0.900 & & & 0.447 & 0.1000 & & & \\
\hline \multirow[t]{2}{*}{ AEC } & A & 217.500 & \multirow[t]{2}{*}{-92.500} & \multirow[t]{2}{*}{$42.52 \%$} & 54.471 & 12.180 & \multirow[t]{2}{*}{-3.850} & \multirow[t]{2}{*}{$<0.001$} & \multirow[t]{2}{*}{$\mathrm{SD}^{*}$} \\
\hline & B & 310.000 & & & 92.623 & 20.711 & & & \\
\hline \multirow[t]{2}{*}{ RR } & A & 3.400 & \multirow[t]{2}{*}{-0.200} & \multirow[t]{2}{*}{$5.88 \%$} & 1.314 & 0.294 & \multirow[t]{2}{*}{-0.497} & \multirow[t]{2}{*}{0.622} & \multirow[t]{2}{*}{ ND } \\
\hline & B & 3.600 & & & 1.231 & 0.275 & & & \\
\hline
\end{tabular}

\section{Statistical Report}

Comparative effect of Katphaladi Churna and Pippalyadi Churna in Tamaka Swasa: For the comparison between the two-group unpaired ' $t$ ' test done for statistical analysis. The result shows there is a significant difference in some of the subjective parameters. In subjective parameter Swasakrichrata, Pratishya and Kanthodhvamsa have a more meaningful difference in Group - B compared to Group - A which is listed in the above-mentioned table.
In objective parameter AEC has a more meaningful difference in Group - B compared to Group - A which is listed above mentioned.

Overall, Group - B shows highly significance than Group - A in subjective and objective parameters respectively by comparing $\mathrm{P}$-value and $\mathrm{t}$ value.

\section{DISCUSSION}

Probable mode of action of Katphaladi Churna (Group-A) in Tamaka Swasa

The probable effect of 'Katphaladi Churna' in Tamaka Swasa by means of its pharmacological 
properties may be explained by the Rasa-Panchaka of drugs used for Churna preparation. Almost all the ingredients are of I Laghu-Tikshna-Ruksha Guna, Usna Virya, Katu Vipaka and Kapha-Vata Samaka properties. Thus, the Katphaladi Churna is a good choice in Tamaka swasa.

The Katu, Tikta and Kasaya Rasa along with Usna Virya does the Deepti of Agni. In further, it takes care of the non-formation of ama, which helps the prevention of disease progression.

Vata and Kapha are of Sheeta Guna in nature. The Virya of the selected Kataphaladi Churna is Usna. Thus, the Usna Virya liquefy the Kapha and pacifies the Vata even though it increases the Pitta.

Probable mode of action of Pippalyadi Churna (Group-B) in Tamaka Swasa

Like Katphaladi Churna the probable mode of action of the Pippalyadi Churna can also be analyzed based on the involvement of respective Dosha, Dushya, type of Srotodushti and Agni and their respective modulation by Rasa-Panchaka of ingredients of Pippalyadi Churna.

Out of the 5 drugs present in the compound preparation, the majority of the drugs present in the formulation were having Katu-Tikta Rasa and then comes Kashaya. Katu, Kashaya and Tikta Rasa helps in Agni Deepthi, Ama Pachana thus facilitating ama Nirharana and Srothosudhi. Kasaya Rasa also pacify the Pitta Dosha along with Kapha. Pitta Dosha is responsible for inflammatory response hence the inflammation in the bronchial tree is also relived by Pippalyadi Churna. The trial drug formulation is Ushna Veerya Pradana and Katu, Madhur Vipaka Pradhana. These properties help in rectifying Vata Dosha as well as Kapha Dosha and help in regaining the Anuloma Gati of Vayu in Pranavaha Srotas.

Pippalyadi Churna has Laghu, Rooksha, Teekshna and Snigdha Guna. Laghu Teekshna and Rooksha Gunas removes the Srotorodha as well as mitigate Kapha Dosha. Snigdha and Ushna Guna helps in mitigating Vata Dosha, thus assisting in relieving the complaints of the disease Tamaka swasa.

\section{Probable mode of action of Anupana}

Madhu (Honey) possess Madhura rasa with Kashaya Anurasa followed by Rooksha Guna and Sheeta Veerya. Its effect on Dosha is as follows. It scrapes Kapha and normalizes Pitta and Rakta. Also, its Madhura Rasa helps to improve the palatability of the compound. Achrya Vagbhata explains it having Swasa-kasaghna property. Besides honey is 'Yogavahi' i.e., when it is used with other herbal preparations it enhances the medicinal qualities of those preparations and also helps them to reach the deeper tissues.

Keeping in mind the above-mentioned properties of honey, it was selected as Anupana in both groups.

\section{Discussion on Results}

- Comparative effect of Katphaladi Churna and Pippalyadi Churna in Tamaka Swasa:

For the comparison between the two-group an unpaired ' $t$ ' test was done for statistical analysis. The result shows there is a statistically significant difference in some of the subjective parameters. In subjective parameter Swasakrichrata, Pratishya and Kanthodhvamsa there was a more meaningful difference in Group - B compared to Group - A.

In objective parameter $\mathrm{AEC}$, the meaner difference was observed in Group - B compared to Group - A. Overall, Group - B shows a highly significant result than Group - A in subjective and objective parameters respectively by comparing ' $\mathrm{P}$ ' value and ' $\mathrm{t}$ ' value.

The probable reason for better symptomatic and overall results in Group-B

On Swasa Krichrata: This symptom of Tamaka Swasa was better relived by Pippalyadi Churna. The cause of Swasa Krichrata is Pratiloma Gati of Vayu and sang of Vata Dosa by Kapha. The Anulomana of Vayu and Kapha Hara property of ingredients of Pippalyadi Churna may have worked to relieve this symptom.

On Kanthodhvamsa: These symptoms are the result of Shook Purana Galasyata which occurs because of Vata Dosa. Vata and Kapha are of Seeta Guna in nature. The Virya of the selected Pippalyadi Churna is Usna. This Usna Virya liquefies the Kapha and paci- 
fies the Vata hence improving the above-said symptoms.

On Kaphanistivana: Katu Tikta Rasa and Usna Virya of Katphaladi Churna acts as Kapha Vilayaka and hence produce mucolytic action thus easing the expectoration of Dusta Kapha.

On Pratishaya: The chief predominant Doshas in Pratishaya is Vata and Kapha and both these factors are better rectified by Pippalyadi Churna with its properties like Vata-Kaphaghna, Ushna Veerya, and Vatanulomana.

On AEC: The rise in eosinophil count is because of the allergic response seen in patients Of Tamak Sawas. Here anti-inflammatory and antihistaminic activities of Pippali, Barangi and Hingu might be a factor for consideration.

Note: On other subjective and objective parameters both trail drugs proved to be equally good. The reason for their similar effects may be the common ingredients Pippli and Karkatasringi.

\section{CONCLUSION}

After analyzing the result obtained from the clinical study the following conclusion can be drawn.

- Illustration of disease review reveals in the close resemblance between natures of Tamaka Swasa with Bronchial Asthma.

- For the disease Tamaka Swasa which is episodic, etiological factors may be exposure to dust, smoke etc. Also, there is no sign of sex and religious incidence seen in this disease.

- Both of the trial drugs Katphaladi Churna and Pippalyadi Churna are statistically significant effects on both subjective parameters and objective parameters.

- While comparing between the groups result shows that Pippalyadi Churna (Group-B) is statistically more effective in Swasa Krichrata, Pratishaya, Kanthodavamsa and AEC than the Katphaladi Churna (Group-A).

- In the overall result, Pippalyadi Churna is more effective than the Katphaladi Churna in the management of Tamaka Swasa.
- The trial drug Katphaladi Churna and Pippalyadi Churna proved to be a safe and effective oral formulation, which helps in the management of Tamaka swasa, when the disease is not too advanced and not associated with complications also when correctly used by the patient as per instructions.

\section{Limitations:}

- The size of the sample was small to draw a generalized conclusion.

- The study of this work was restricted to a particular geographical area only.

Recommendations (For further study):

- The study should be conducted on a larger sample with a longer duration.

- The study should be done by using the recent advancement in the field of medical science for further re-establishment of Ayurvedic therapeutics.

- The same Katphaladi Churna and Pippalyadi Churna study should be done after Shodana therapy.

- The awareness should be brought regarding the preventive measures to the public.

\section{REFERENCES}

1. Pandeya Kashinath. Gorkhanatha Chaturvedi. Charaka Samhitha. Chikitsa Sthan. Chapter17. Shloka 55-62. Varanasi: Chaukambha Bharathi Academy. P: 516 (2009).

2. Mohan Harsh. Textbook Of Pathology. 4th Edn. Delhi: Jaypee $14^{\text {th }}$ Chapter. P. 455 (2000).

3. Anthony S. Fauci. Dennis L. Kasper. Dan L. Longo. Eugene Braunwald. Stephen L. Hauser. J. Larry Jameson. Joseph Loscalzo Editors. Harrison's Principles Of Internal Medicine. 19th Edn. New Delhi: Tata Mcgraw-Hill. 309 ${ }^{\text {th }}$ Chapter. P. 1669 (2015).

4. Anonymous. The Ayurvedic Formulary Of India. English Translation. Govt. Of India, Dept. Of Indian Systems Of Medicine \& Homoeopathy Part II, Delhi: The Controller Of Publications Civil Line Page No 91, 92,171 (2000)

5. Anthony S. Fauci. Dennis L. Kasper. Dan L. Longo. Eugene Braunwald. Stephen L. Hauser. J. Larry Jameson. Joseph Loscalzo Editors. Harrison's Principles Of 
Internal Medicine. 19th Edn. New Delhi: Tata Mcgraw-Hill. 309 ${ }^{\text {th }}$ Chapter. P. 1669 (2015).

6. Anthony S. Fauci. Dennis L. Kasper. Dan L. Longo. Eugene Braunwald. Stephen L. Hauser. J. Larry Jameson. Joseph Loscalzo Editors. Harrison's Principles Of Internal Medicine. 19th Edn. New Delhi: Tata Mcgraw-Hill. 309 ${ }^{\text {th }}$ Chapter. P. 1669 (2015).

7. Murthy K.R. Srikanta. Sarngadhar Samhita. Madhyam Khanda. $6^{\text {th }}$ Chapter. Shloka: 42, Varanasi: Chaukhambha Orientalia. P. 89 (2009).

8. Tewari P.V. Kashyap Samhita. Chikitsa Sthana $2^{\text {nd }}$ Chapter. Shloka: 12. Varanasi: Chaukhambha Orientalia. P. 164 (2006).

9. Murthy K.R. Srikanta. Sarngadhar Samhita. Madhyam Khanda. $6^{\text {th }}$ Chapter. Shloka: 42, Varanasi: Chaukhambha Orientalia. P. 89 (2009).

10. Tewari P.V. Kashyap Samhita. Chikitsa Sthana $2^{\text {nd }}$ Chapter. Shloka: 12. Varanasi: Chaukhambha Orientalia. P. 164 (2006).

11. Pandeya Kashinath. Gorkhanatha Chaturvedi. Charaka Samhitha, Sutra Sthana. Chapter19. Shloka 4. Varanasi: Chaukambha Bharathi Academy. P: 386 (2009).

12. Murthy K.R. Srikanta. Sarngadhar Samhita. Madhyam Khanda. $6^{\text {th }}$ Chapter. Shloka: 42, Varanasi: Chaukhambha Orientalia. P. 89 (2009).

13. Tewari P.V. Kashyap Samhita. Chikitsa Sthana $2^{\text {nd }}$ Chapter. Shloka: 12. Varanasi: Chaukhambha Orientalia. P. 164 (2006).

14. Anonymous. The Ayurvedic Formulary Of India. English Translation. Govt. Of India, Dept. Of Indian Systems Of Medicine \& Homoeopathy Part II, Delhi: The Controller Of Publications Civil Line Page No 91, 92,171 (2000)

\section{Source of Support: Nil Conflict of Interest: None Declared \\ How to cite this URL: Ashutosh Kr. Bhardwaj \& Prashanth Bhat: A Comparative Clinical Evaluation Of Katphaladi Churna And Pippalyadi Churna In Management Of Tamaka Swasa. International Ayurvedic Medical Journal \{online\} 2021 \{cited November 2021\} Available from: http://www.iamj.in/posts/images/upload/3163 3170.pdf}

